\title{
Evidence for the co-circulation of dengue virus type 3 genotypes III and $V$ in the Northern region of Brazil during the 2002-2004 epidemics
}

\author{
Meri Bordignon Nogueira $/{ }^{1} / 2$, Vanessa Stella, Juliano Bordignon, Weber Cheli Batista ${ }^{3}$, \\ Luana de Borba, Luis Hildebrando Pereira da Silva ${ }^{3}$, Federico Guillermo Hoffmann, \\ Christian Macagnan Probst, Claudia Nunes Duarte dos Santos/ ${ }^{+}$
}

\begin{abstract}
Instituto Carlos Chagas-Fiocruz, Rua Prof. Algacyr Munhoz Maeder 3.775, Cidade Industrial, 81350-010 Curitiba, PR, Brasil ${ }^{1}$ Departamento de Patologia Médica ${ }^{2}$ Laboratório de Virologia, Hospital de Clínicas, Universidade Federal do Parará, Curitiba, PR, Brasil ${ }^{3}$ Unidade de Virologia, Instituto de Pesquisa em Patologias Tropicais, Porto Velho, RO, Brasil
\end{abstract}

The reintroduction of dengue virus type 3 (DENV-3) in Brazil in 2000 and its subsequent spread throughout the country was associated with genotype III viruses, the only DENV-3 genotype isolated in Brazil prior to 2002. We report here the co-circulation of two different DENV-3 genotypes in patients living in the Northern region of Brazil during the 2002-2004 epidemics. Complete genomic sequences of viral RNA were determined from these epidemics, and viruses belonging to genotypes $V$ (Southeast Asia/South Pacific) and III were identified. This recent co-circulation of different DENV-3 genotypes in South America may have implications for pathological and epidemiological dynamics.

Key words: dengue virus type 3 - genotype III and V - co-circulation - phylogenetic analysis - Amazon

Dengue is an emerging infectious disease affecting almost 50 million people in tropical and subtropical regions of the world. Dengue fever (DF) and dengue hemorrhagic fever (DHF) are caused by four closely related, but antigenically different dengue virus serotypes 1-4 (DENV-1-4) (Gubler \& Clark 1995). Since the introduction of the DENV into Brazil in 1986, more than four million cases of dengue have been reported (Cordeiro et al. 2007), and the incidence of severe clinical symptoms has increased. No vaccine or specific therapeutic antiviral measures are available.

Several studies have suggested that individuals experiencing a second dengue infection with a heterologous serotype are at greater risk for developing DHF or dengue shock syndrome (DSS) (Cummings et al. 2005, Halstead et al. 2005). However, DHF and DSS are also observed in primary cases, and not all secondary infections correspond to severe forms of the disease. Studies based on molecular epidemiology have provided evidence that differences in virulence between viral strains could play a role in the severity of the disease (Mangada \& Igarashi 1998, Rico-Hesse 2003).

Major dengue virus epidemics occurred in Brazil in 1986 and 1990, due to the introduction of DENV-1 and -2 , respectively, and the subsequent spread of these serotypes throughout the country. DENV-3 reappeared in 1994 in Central America (Nicaragua and Panama) after 17 years of absence, and later spread to Mexico and the Caribbean (CDC 1995, Guzman et al. 1996, Usuku et al. 2001). In 2000, the presence of this serotype was re-

Financial support: Fiocruz, CNPq (proc. 410593/2006-0), Fundação Araucária (proc. 5-1-8892), CYTED/RIVE network

+ Corresponding author: clsantos@tecpar.br; clsantos@fiocruz.br

Received 11 March 2008

Accepted 4 July 2008 ported in two countries in South America: Brazil and Venezuela (Nogueira et al. 2001, Uzcategui et al. 2003). DENV-3 was initially isolated in December 2000 in the state of Rio de Janeiro (RJ), in Southeastern Brazil (Nogueira et al. 2005). The virus has since been detected in almost all Brazilian states, establishing conditions of hyperendemicity with serotypes 1,2 and 3. DENV-3 genotype III (Sri Lanka/India) was identified in all affected states during the epidemics of 2001 to 2004, and caused the one of most severe epidemic with the largest number of reported cases, greatest severity of clinical manifestations in primary infections in particular, and the largest number of confirmed deaths (Nogueira et al. 2005). In 2002, Brazil contained almost $80 \%$ of the one million cases of dengue infection in the Americas, with almost 800,000 dengue cases and 150 deaths attributed to DENV-3 (www. saude.gov.br). Recently, Figueiredo et al. (2008) reported the circulation of DENV-3 genotype I in Minas Gerais.

In the Amazonian state of Rondônia (RO), located in the Northern region of Brazil, the first confirmed cases of dengue dated from 1997, and the first outbreak occurred in 2000, with 2,759 cases (http://portal.saude.gov.br/portal/ arquivos/pdf/taxa_incidencia_dengue2007.pdf). DENV-1 was isolated in $20 \overline{0} 1$ in Porto Velho (the largest city in the state). In 2002, following the introduction of DENV-3, the state experienced an epidemic, in which unusual clinical symptoms, such as meningoencephalitis, were observed (Nogueira et al. 2005, WC Batista, unpublished observations). Given the high incidence of severe clinical symptoms related to primary DENV infections observed in the 2002 epidemic, we decided to characterize the genome of the virus circulating in the Northern region of Brazil and determine its phylogenetic relationship with other DENV-3 strains. Identification of the circulating DENV genotypes is important, as it has been demonstrated that some strains are more frequently associated with severe disease than others (Leitmeyer et al. 1999, Pandey \& Igarashi 2000, Rico-Hesse 2003). 


\section{PATIENTS, MATERIALS AND METHODS}

Clinical samples and viruses - A serum sample from a dengue positive patient who had traveled to an area of epidemic dengue in RJ in Southeastern Brazil, and eight serum samples from patients living in Acre (AC) and $\mathrm{RO}$ in Northern Brazil (Table I, Fig. 1) were kindly provided by LACEN, Curitiba and IPEPATRO, Porto Velho, respectively. All patients were diagnosed with DF. These samples were used for the characterization of DENV genomes.

$R N A$ extraction and $R T-P C R$ - Viral RNA was isolated from $140 \mu$ l of patient serum samples, taken during the acute phase of the disease and/or from $140 \mu \mathrm{l}$ of purified virus prepared from cell culture supernatants after three passages in C6/36 cells, as described elsewhere (Duarte dos Santos et al. 2002). The QIAamp Viral RNA Mini Kit (Qiagen, Valencia, USA) was used, following the manufacturer's instructions. Complete genomes were amplified by means of overlapping RT-PCR products, using $5 \mu \mathrm{l}$ of RNA and random primers (Invitrogen, Carlsbad, USA) and Improm II Reverse Transcriptase (Promega, Madison, USA), for $1 \mathrm{~h}$ at $47^{\circ} \mathrm{C} ; 5 \mu \mathrm{l}$ of cDNA were used for the amplification reaction with the High Fidelity TripleMaster ${ }^{\circledR}$ PCR System (Eppendorf, Hamburg, Germany) and specific primers, according to the protocols supplied with the kit. Briefly, the thermocycling conditions consisted of $94^{\circ} \mathrm{C} / 3 \mathrm{~min}$, followed by 35 cycles of $94^{\circ} \mathrm{C} / 30 \mathrm{~s}$, $55-58^{\circ} \mathrm{C} / 30 \mathrm{~s}$ and $68^{\circ} \mathrm{C} / 3 \mathrm{~min}$.

Sequencing strategy, multiple sequence alignment and phylogenetic analysis - The amplicons were directly sequenced using a Thermo Sequenase kit (USB Inc, Ohio, USA) on an ABI3100 device, with the BigDye7 Terminator method (Applied Biosystems, Warrington, UK). Nucleotide sequences were analyzed with a Phred/Phrap/Consed package (www.phrap.org). Sequences were obtained from the 5' and 3' UTR of the BR DEN3/290-02, BR DEN3/95-04, BR DEN3/97-04, BR DEN3/98-04, BR DEN3/RO1-02 and BR DEN3/RO2-02 samples after uncapping and RNA ligation, as described elsewhere (Duarte dos Santos et al. 2000). Primer sequences are available upon request.

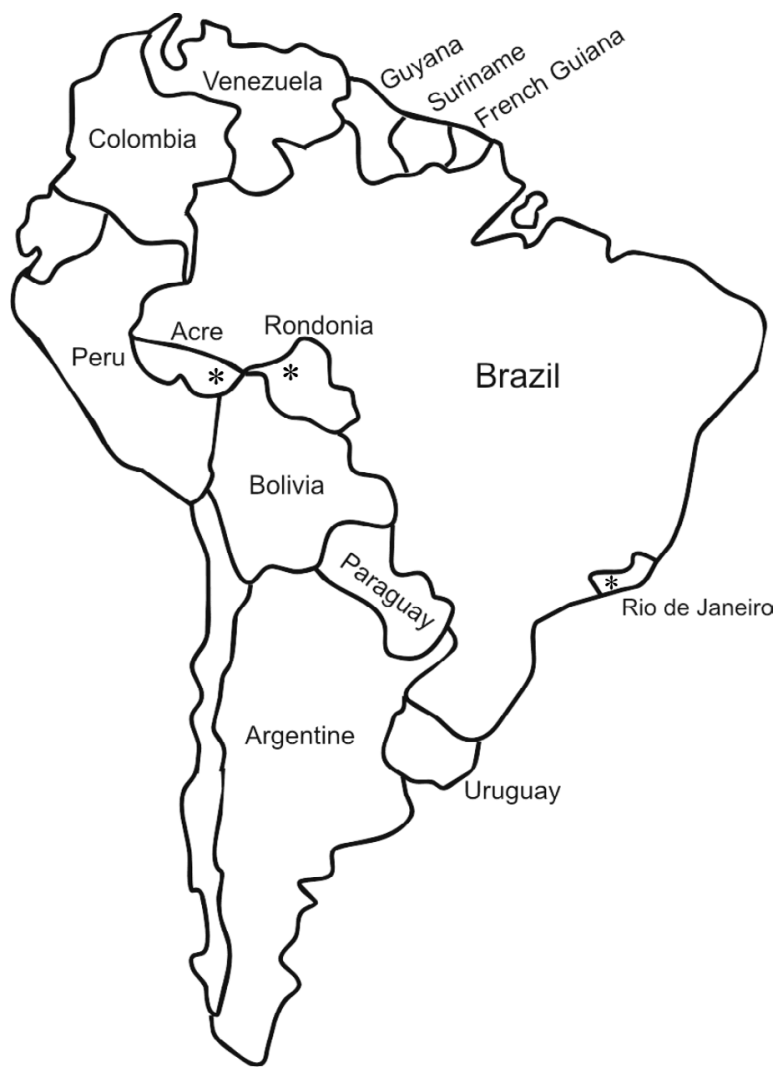

Fig. 1: map of Brazil, showing the areas from which DENV-3 viruses were isolated $(*)$ and the borders of the countries of South America.

Sequence analyses - For phylogenetic and comparative purposes, we assembled a representative panel of complete DENV-3 genome sequences from GenBank (supplementary data). All sequences were aligned using CLUSTALW (Thompson et al. 1994). Phylogenies were estimated in a Maximum likelihood framework using Treefinder (version April, Jobb et al. 2004). We selected the best-fit model of nucleotide substitution based on the

TABLE I

Patient code, GeneBank accession number, origin, data, nucleotide sequence and genotype

\begin{tabular}{|c|c|c|c|c|c|}
\hline Patient & GeneBank & State of origin/city & Month/year & Genome sequence/nt & $\begin{array}{l}\text { DENV-3 } \\
\text { Genotype }\end{array}$ \\
\hline BR DEN3/290-02 & EF629369 & RJ/Rio de Janeiro & $01 / 2002$ & Complete/10707 & III \\
\hline BR DEN3/95-04 & EF629366 & AC/Rio Branco & $11 / 2004$ & Complete/10707 & III \\
\hline BR DEN3/97-04 & EF629367 & AC/Rio Branco & $11 / 2004$ & Complete/10707 & III \\
\hline BR DEN3/98-04 & EF629368 & AC/Rio Branco & $11 / 2004$ & Complete/10707 & III \\
\hline BR DEN3/RO1-02 & EF629370 & RO/Porto Velho & $11 / 2002$ & Complete/10696 & $\mathrm{V}$ \\
\hline BR DEN3/RO2-02 & EF629373 & RO/Porto Velho & $03 / 2002$ & Partial/10324 & $\mathrm{V}$ \\
\hline BR DEN3/RO3-02 & $\begin{array}{l}1810-3470(\text { EF629375) } \\
4300-5500(\text { EF629374) } \\
6010-10220(\text { EF629376) }\end{array}$ & RO/Porto Velho & $02 / 2002$ & Partial $/ 7070^{a}$ & $\mathrm{~V}$ \\
\hline BR DEN3/RO4-02 & EF629371 & RO/Porto Velho & $08 / 2002$ & Partial $/ 367^{b}$ & $\mathrm{~V}$ \\
\hline BR DEN3/RO5-02 & EF629372 & RO/Porto Velho & $11 / 2002$ & Partial $/ 227^{b}$ & $\mathrm{~V}$ \\
\hline
\end{tabular}

$a$ : 1810-3470 (genes E and NS1), 4300-5500 (genes NS2B and NS3), 6010-10220 (genes NS3, NS4A, NS4B and NS5); $b$ : gene C; AC: Acre; RJ: Rio de Janeiro; RO: Rondônia. 
Bayesian Information Criterion using the Model Proposal routine from Treefinder. Support for the nodes was evaluated by running 500 bootstrap pseudoreplicates. The likelihood scores of competing hypotheses were obtained using the Shimodaira-Hasegawa (SH) topology test (Shimodaira \& Hasegawa 1999), as implemented in Treefinder (Jobb et al. 2004).

\section{RESULTS}

In order to characterize the DENV strains circulating in Brazil and determine their relationships with other DENV strains, we examined clinical samples from RO (epidemic in 2002) and AC (epidemic in 2004), and from RJ (epidemic in 2002), located in the Northern and Southeastern regions of Brazil, respectively. Nine DENV isolated from human samples collected in these three different geographical areas of Brazil were sequenced after three passages in C6/36 cells. Complete genome sequences were determined for five of these viral isolates: BR DEN3/290-02, BR DEN3/95-04, BR DEN3/97-04, BR DEN3/98-04 (alignment of $10707 \mathrm{nt}$ ) and BR DEN3/ RO1-02 (alignment of $10696 \mathrm{nt}$ ). In addition, an almost complete genome sequence of the BR DEN3/RO2-02 virus (starting at position 378 and ending at position 10696), as well as three fragments covering $~ 70 \%$ of the genome from the BR DEN3/RO3-02 strain (corresponding to positions $1810-3470,4300-5500$ and 6010 10220) were determined. The BR DEN3/RO1-02 and BR DEN3/RO2-02 sequences had an $11 \mathrm{bp}$ deletion in the 3'UTR. We also determined partial genomic sequences from viral RNA extracted directly from the plasma of two Rondônian patients (BR DEN3/RO5-02, from nt 135 to 361 and BR DEN3/RO4-02, from nt 132 to 498 of DENV-3 RNA). Both samples were identified as belonging to genotype $\mathrm{V}$. We compared complete genomic sequences between five dengue viruses and $7070 \mathrm{nt}$ between seven dengue viruses (due mainly to the fragmentation of BR DEN3/RO3-02). Their nucleotide and amino acid similarities are displayed in Table II.

Comparisons of complete genome nucleotide sequences showed that BR DEN3/290-02 was most similar to BR74886/02 (99.6\% identity, AY679147), which was isolated from the liver of a patient who died from the disease in RJ (Miagostovich et al. 2002, 2006). BR DEN3/ RO1-02 was found to be closely related to $80-2$ (99.7\% identity, AF317645), a virus from a DF patient isolated in 1980 in China. As can be seen in Fig. 2, the samples from
RO formed a separate cluster, which was closely related to the DENV-3 H-87 (M93130), D3-73NIID (AB111085) and 80-2 (AF317645) isolates, which belong to genotype V (Southeast Asia/South Pacific), and are clearly different from those from $\mathrm{AC}$ and $\mathrm{RJ}$ isolates, which clustered with genotype III (Sri Lanka/India, AY099336). This finding is remarkable, as the three genotype $\mathrm{V}$ viruses were isolated in Asia in 1956, 1973 and 1980, respectively.

Brazilian DENV-3 isolates grouped into two separate clides: all samples isolated from Acre grouped with an isolate from RJ, whereas all samples isolated from $\mathrm{RO}$ were clustered in a separate clade (Fig. 2). Bootstrap support for nodes separating the two groups of Brazilian samples was strong (Fig. 2), and a tree where all sequences from Brazil were clustered in a single group providing significantly worse fit to the data (SH test $\mathrm{p}<0.001$ ).

\section{DISCUSSION}

A displacement of serotypes 1 and 2 of DENV was documented in Brazil after the introduction of a highly virulent genotype of DENV-3 (genotype III, Sri Lanka/ India) in 2002 (Nogueira et al. 2005). The rapid spread of DENV-3 caused severe epidemics in almost all Brazilian regions in the three years following its introduction (Nogueira et al. 2005, De Simone et al. 2004). The Northern region of Brazil suffered DENV-3 epidemics between 2002 and 2004. Different clinical profiles were observed during this epidemic period, with DHF/DSS and encephalitis cases identified in RO, whereas only DF was observed in AC. During the DENV-3 epidemic in RO in 2002, several atypical encephalitis cases were observed in patients testing positive serologically for dengue, but it was not possible to isolate virus from those patients. It remains unclear whether that clinical pattern was exclusively related to DENV-3, or was the result of co-infection with other viruses, such as the SLE or Rocio viruses (Rocco et al. 2005, Mondini et al. 2007). However, we cannot exclude the possibility that the observed unusual clinical presentations were exclusively due to the DENV infections, taking into account the results of Domingues et al. (2008) which showed that $21.2 \%$ of patients with dengue infection exhibited involvement of the central nervous system. In AC, DENV-3 was first isolated in 2004 and no severe case was observed at that time (Brazilian Ministry of Health, SVS, www.saude.gov.br).

We compared viral genomes amplified directly from serum samples or from insect cells infected with viruses

TABLE II

Nucleotide (bottom) and amino acid (top) similarity between brazilian dengue virus type 3 (BR DEN3) isolates described in this paper

\begin{tabular}{lcccccrr}
\hline & DEN3/95-04 & DEN3/98-04 & DEN3/290-02 & DEN3/97-04 & DEN3/RO2-02 & DEN3/RO1-02 & DEN3/RO3-02 \\
\hline DEN3/95-04 & & 99.9 & 99.9 & 99.6 & 98.1 & 98.1 & 98.1 \\
DEN3/98-04 & 99.9 & & 99.8 & 99.6 & 98.1 & 98.1 & 98.1 \\
DEN3/290-02 & 99.6 & 99.6 & & 99.7 & 98.1 & 98.1 & 98.1 \\
DEN3/97-04 & 99.4 & 99.4 & 99.5 & & 97.9 & 97.9 & 97.9 \\
DEN3/RO2-02 & 94.5 & 94.5 & 94.5 & 94.4 & & 100.0 & 100.0 \\
DEN3/RO1-02 & 94.5 & 94.5 & 94.5 & 94.4 & 100.0 & & 100.0 \\
DEN3/RO3-02 & 94.5 & 94.5 & 94.5 & 94.4 & 100.0 & 100.0 & \\
\hline
\end{tabular}




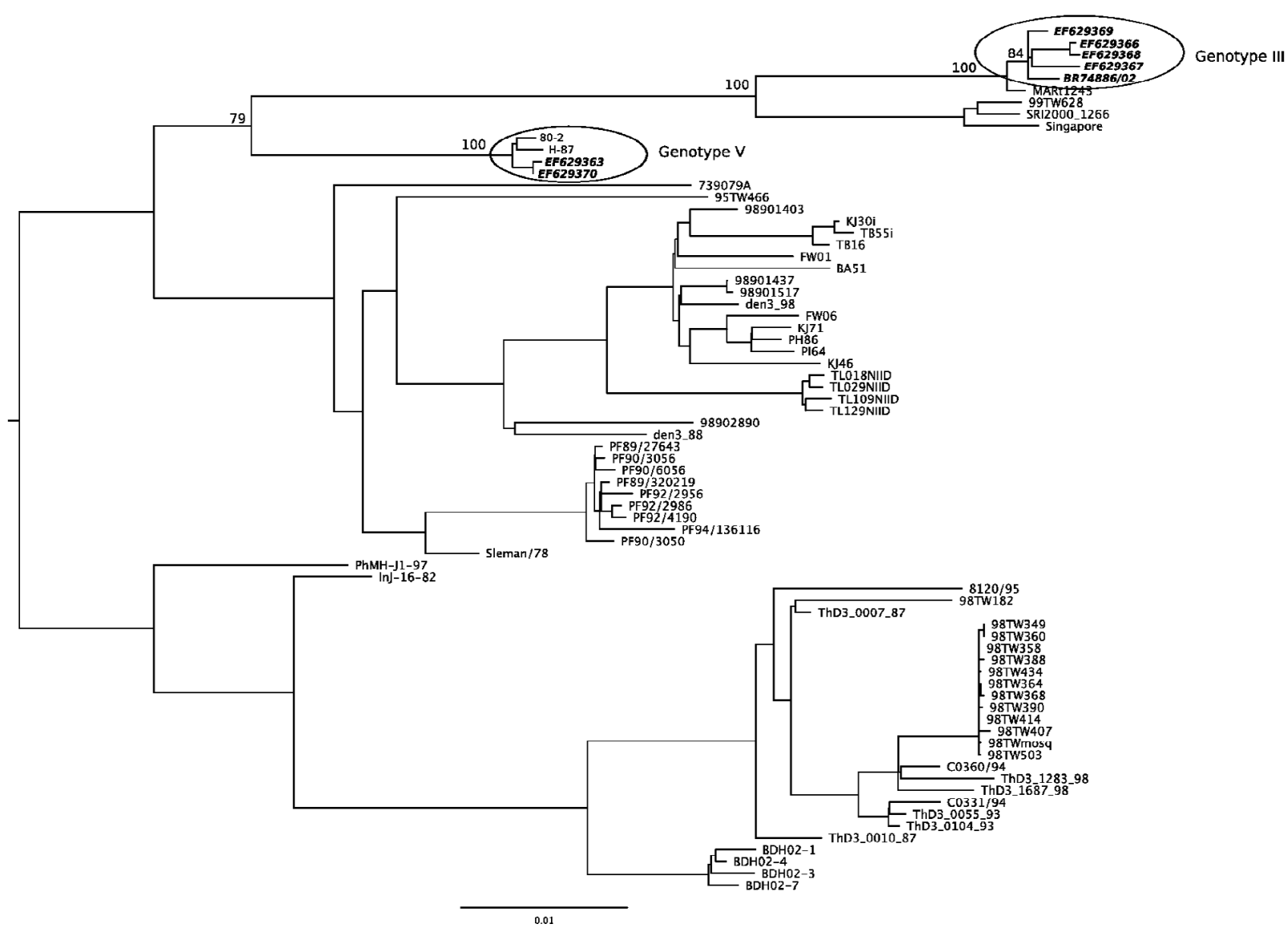

Fig. 2: maximum likelihood phylogram describing phylogenetic relationships among the Brazilian DENV-3 isolates and the reference panel based on the complete genome nucleotide sequences. Brazilian samples are in italics and in bold. Bootstrap values are provided next to the relevant nodes. GenBank accession numbers of all virus strains included in this analysis are listed in the supplementary data.

circulating in Northern Brazil, samples of DENV-3 from $\mathrm{RJ}$, and those retrieved from databases. It should be emphasized that only DENV-3 genotype III was identified during the 2002 to 2003 epidemic in samples from Porto Velho (Aquino et al. 2006) and RJ (Nogueira et al. 2005), and this genotype is the only one to have been implicated in DENV-3 epidemics in the Americas (Usuku et al. 2001, Messer et al. 2003, Uzcategui et al. 2003, Peyrefitte et al. 2005, Rigau-Pérez \& Laufer 2006, Ocazionez et al. 2006). When samples received from Porto Velho were used to infect $\mathrm{C} 6 / 36$ cells, they displayed a cytotoxic effect not seen with other DENV-3 viral isolates (data not shown). These findings led to the molecular characterization of these samples. Viral genome sequences of five isolates indicated that DENV-3 genotypes III and V cocirculated during the 2002 epidemic in RO. We analyzed three samples from AC, all of which were of genotype III, as well as the isolate from RJ. However, due to the small number of samples studied, we cannot rule out the possibility that another genotype was also circulating in those regions. The virus collection of our institute (ICCFiocruz) does not include DENV-3 strains H87 (M93130, Osatomi \& Sumiyoshi 1990), 80-2 (AF317645), or any other DENV-3 genotype V strain, and these strains had never been manipulated in our laboratories. Sample contamination was therefore highly unlikely. Further- more, two of the eight samples from RO and seven of the 12 samples from AC tested negative. Moreover, viral RNA for BR DEN3/RO4-02 and BR DEN3/RO5-02 was obtained directly from plasma samples. It is worth mentioning that our data was recently corroborated by similar findings in Colombia (José Usme Ciro and Juan Carlos Gallego-Gómez, unpublished observations) which showed that DENV-3 genotype $\mathrm{V}$ had also been isolated from human cases in Colombia during the 20032005 epidemics.

Aquino et al. (2006) recently demonstrated by phylogenetic analysis with partial nucleotide sequences for the E protein and 3'UTR that Brazilian DENV-3 (particularly from RO) are grouped with samples from Sri Lanka, Samoa and other American genotype III DENV-3. These authors also suggested that DENV-3 had been introduced at least twice into Brazil, once via RJ and the second via the Caribbean countries. More recently, Figueiredo et al. (2008) demonstrated the co-circulation of two genotypes of DENV-3 in Minas Gerais from 2002 to 2004. A larger number of viral isolates should be analyzed in other Brazilian states and South American countries to identify the circulating dengue genotypes, and to track the dynamics of virus introduction and maintenance in nature. The DENV-3 genotype classification is a controversial matter. Wittke et al. (2002) have re-classified the China 
80-2 strain, formerly classified as genotype I, as genotype $\mathrm{V}$ based on $\mathrm{E}$ gene sequences. Aquino et al. (2006) have followed this classification. On the other hand, Figueiredo et al. (2008), using C/prM gene sequences, classified the same strain as belonging to genotype I. We decided to adopt the Wittke et al. (2002) classification as it provided a higher level of genotype discrimination. Following this, we classified our strains as belonging to genotypes III (AC) and V (RO). However, we acknowledge that DENV-3 genotype classification is still controversial. Intra-serotype genetic diversity in DENV vary greatly on a temporal scale, and it has became clear that individual lineages or entire virus clades frequently arise, persist for a period of time, and then disappear (Zhang et al. 2005). Therefore, more precise criteria for genotype classification of dengue virus are essential to avoid different nomenclature for similar strains.

The results obtained in this study raise some intriguing questions: how can a recent clinical viral isolate from South America display 99.9\% identity with a laboratory viral strain (DENV-3 80-2) isolated from a DF patient in China? Will it be possible to trace the route by which these viruses entered the Americas? Interestingly, the DENV-3 genotype V strains H-87 (L11423) isolated from a human case in the Philippines in 1956, D3-73NIID (AB111085) isolated in 1973 from an imported human case in Japan, and 80-2 (AF317645) isolated in China in 1980, also display a remarkably high level of nucleotide sequence conservation (over 99\%) with each other and with some of the viruses included in this study. The most dramatic case of sequence similarity is illustrated by the three viral isolates from RO; they display $100 \%$ sequence identity with each other. These three cases are probably linked epidemiologically, but further efforts are needed to elucidate whether they represent a single chain of infection.

Further genome characterization of viruses from other South American countries that have also experienced unusual DENV-3 epidemics should shed light on this issue.

\section{ACKNOWLEDGEMENTS}

To Paulo Arauco for technical help with sequencing and Anaclete Felinni, from LACEN-Curitiba, for the dengue serum samples.

\section{REFERENCES}

Aquino VH, Anatriello E, Gonçalves PF, Silva EV, Vasconcelos PFC, Vieira DS, Batista WC, Bobadilla ML, Vasquez C, Moran M, Figueiredo LTM 2006. Molecular epidemiology of dengue type 3 virus in Brazil and Paraguay, 2002-2004. Am J Trop Med Hyg 75: $710-715$.

CDC - Center for Disease Control and Prevention 1995. Dengue type 3 infection: Nicaragua and Panama. JAMA 273: 840-841.

Cordeiro MT, Schstzmayr HG, Nogueira RMR, Oliveira VF, Melo WT, Carvalho EF 2007. Dengue and dengue hemorrhagic fever in the State of Pernambuco, 1995-2006. Rev Soc Bras Med Trop 40: 605-611.

Cummings DA, Schwartz IB, Billings L, Shaw LB, Burke DS 2005. Dynamic effects of antibody-dependent enhancement on the fitness of viruses. Proc Natl Acad Sci USA 102: 15259-15264.
De Simone TS, Nogueira RMR, Araújo ESM, Guimarães FR, Santos FB, Schatzmayr HG, Souza RV, Teixeira FG, Miagostovich MP 2004. Dengue virus (DENV) surveillance: the co-circulation of DENV-1, 2 and 3 in the state of Rio de Janeiro, Brazil. Trans $R$ Soc Trop Med Hyg 98: 553-562.

Domingues RB, Kuster GW, Onuki-Castro FL, Souza VA, Levi JE, Pannuti CS 2008. Involvment of the central nervous system in patients with dengue virus infection. J Neurol Sci 267: 36-40.

Duarte dos Santos CN, Frenkiel MP, Courageot MP, Rocha CF, Vazeille-Falcoz MC, Wien MW, Rey FA, Deubel V, Desprès $P$ 2000. Determinants in the envelope E protein and viral RNA helicase NS3 that influence the induction of apoptosis in response to infection with dengue type 1 virus. Virology 274: 292-308.

Duarte dos Santos CN, Rocha CF, Cordeiro M, Fragoso SP, Rey FA, Deubel V, Desprès P 2002. Sequence analysis of dengue type-1 virus strains obtained in Brazil in 1990 and 2001 reveal a remarkable conservation of the structural proteins but amino acid differences in the non-structural proteins. Virus Res 90: 197-205.

Figueiredo L, Cecillio AB, Ferreira GP, Drumond BP, Oliveira JG, Bonjardim CA, Ferreira PCP, Kroon EG 2008. Dengue virus 3 genotype 1 associated with dengue fever and dengue hemorrhagic fever, Brazil. Emerg Infect Dis 14: 314-316.

Gubler DJ, Clark GG 1995. Dengue/Dengue hemorrhagic fever: the emergence of a global health problem. Emerg Infect Dis 1: 55-57.

Guzman MG, Vazquez S, Martinez E, Rodriguez AM, Kouri RG, De Los Reyes J, Acevedo F 1996. Dengue in Nicaragua, 1994: reintroduction of serotype 3 in the Americas. Bol Of Sanit Panam 121: $102-110$.

Halstead SB, Heinz FX, Barrett AD, Roehrig JT 2005. Dengue virus: molecular basis of cell entry and pathogenesis. Vaccine 4: 849-856.

Jobb G, von Haeseler A, Strimmer K 2004. TREEFINDER: a powerful graphical analysis environment for molecular phylogenetics. BMC Evol Biol 4: 18.

Leitmeyer KC, Vaughn DW, Watts DM, Salas R, Chacon IV, Ramos C, Rico-Hesse R 1999. Dengue virus structural differences that correlate with pathogenesis. $J$ Virol 73: 4738-4747.

Mangada MN, Igarashi A 1998. Molecular and in vitro analysis of eight dengue type 2 viruses isolated from patients exhibiting different disease severities. Virology 244: 458-466.

Messer WB, Gubler DJ, Harris E, Sivananthan K, Silva AM 2003. Emergence and global spread of a dengue serotype 3, subtype III virus. Emerg Infect Dis 9: 800-809.

Mondini A, Bronzoni RV, Cardeal IL, Dos Santos TM, Lázaro E, Nunes SH, Silva GC, Madrid MC, Rahal P, Figueiredo LT, Chiaravalloti FN, Nogueira ML 2007. Simultaneous infection by DENV-3 and SLEV in Brazil. J Clin Virol 40: 84-86.

Miagostovich MP, Santos FB, Fumian TM, Guimarães FR, Costa EV, Tavares FN, Oliveira JC, Nogueira RMR 2006. Complete genetic characterization of a Brazilian dengue virus type 3 strain isolated from a fatal outcome. Mem Inst Oswaldo Cruz 101: 307-313.

Miagostovich MP, Santos FB, Simone TS, Costa EV, Filippis AMB, Schatzmayr HG, Nogueira RM 2002. Genetic characterization of dengue virus type 3 isolates in the State of Rio de Janeiro, 2001. Braz J Med Biol Res 35: 869-872.

Nogueira RMR, Miagostovich MP, Filippis AMB, Pereira MAS, Schatzmayr HG 2001. Dengue virus type 3 in Rio de Janeiro, Brazil. Mem Inst Oswaldo Cruz 96: 925-926.

Nogueira RMR, Schatzmayr HG, Filippis AMB, Santos FB, Cunha 
RV, Coelho JO, De Souza LJ, Guimarães FR, de Araújo ES, De Simone TS, Baran M, Teixeira G Jr, Miagostovich MP 2005. Dengue virus type 3, Brazil, 2002. Emerg Infect Dis 11: 1376-1381.

Ocazionez RE, Cortés FM, Villar LA, Gómez SY 2006. Temporal distribution of dengue virus serotypes in Colombian endemic area and dengue incidence. Re-introduction of dengue-3 associated to mild febrile illness and primary infection. Mem Inst Oswaldo Cruz 101: 725-731.

Osatomi K, Sumiyoshi H 1990. Complete nucleotide sequence of dengue type 3 virus genome RNA. Virology 176: 643-647.

Pandey BD, Igarashi A 2000. Severity-related molecular differences among nineteen strains of dengue type 2 viruses. Microbiol Immunol 44: 179-188.

Peyrefitte CN, Pastorino BAM, Bessaud M, Gravier P, Tock F, Couissinier-Paris P, Martial J, Huc-Anais P, Césaire R, Grandadam M, Tolou HJ 2005. Dengue type 3 virus, Saint Martin, 20032004. Emerg Infect Dis 11: 757-761.

Rico-Hesse R 2003. Microevolution and virulence of dengue viruses. Adv Virus Res 59: 315-341.

Rigau-Pérez JG, Laufer MK 2006. Dengue-related deaths in Puerto Rico, 1992-1996: Diagnosis and clinical alarm signals. Clin Infect Dis 42: 1241-1246.

Rocco IM, Santos CLS, Bisordi I, Petrella SMCN, Pereira LE, Souza RP, Coimbra TLM, Bessa TAF, Oshiro FM, Lima LBQ, Cerroni MP, Marti AT, Barbosa VM, Katz G, Suzuki A 2005. ST Louis
Encephalitis virus: first isolation from a human in São Paulo State, Brazil. Rev Inst Med Trop Sao Paulo 47: 281-285.

Shimodaira H, Hasegawa H 1999. Multiple comparisons of log-likelihoods with applications to phylogenetic inference. Mol Biol Evol 16: 1114-1116.

Thompson JD, Higgins DG, Gibson TJ 1994. CLUSTAL W: improving the sensitivity of progressive multiple sequence alignment through sequence weighting, position-specific gap penalties and weight matrix choice. Nucleic Acids Res 22: 4673-4680.

Usuku S, Castillo L, Sugimoto C, Noguchi Y, Yogo Y, Kobayashi $\mathrm{N}$ 2001. Phylogenetic analysis of dengue-3 viruses prevalent in Guatemala during 1996-1998. Arch Virol 146: 1381-1390.

Uzcategui NY, Comach G, Camacho D, Salcedo M, Cabello de Quintana M, Jimenez M, Sierra G, Uzcategui RC, James WS, Turner S, Holmes EC, Gould EA 2003. Molecular epidemiology of dengue virus type 3 in Venezuela. J Gen Virol 84: 1569-1575.

Wittke V, Robb TE, Thu HM, Nisalak A, Nimmannitya S, Kalayanrooj S, Vaughn DW, Endy TP, Holmes EC, Aaskov JG 2002. Extinction and rapid emergence of strains of dengue 3 virus during an interpidemic period. Virology 301: 148-156.

Zhang C, Mammen Jr MP, Chinnawirotpisan P, Klungthong C, Rodpradit P, Monkongdee P, Nimmannitya S, Kalayanarooj S, Holmes EC 2005. Clade replacements in dengue virus serotypes 1 and 3 are associated with changing serotype prevalence. $J$ Virol 79: $15123-15130$ 
TABLE S1

DEN3 complete genome sequences used in the analysis

\begin{tabular}{|c|c|}
\hline GenBank & CodeDescription \\
\hline AY679147 & Dengue virus type 3 strain BR74886/02, complete genome \\
\hline AY099337 & Dengue virus type 3 isolate D3/H/IMTSSA-MART/1999/1243, complete genome \\
\hline DQ675533 & Dengue virus type 3 isolate 99TW628, complete genome \\
\hline AY099336 & Dengue virus type 3 isolate D3/H/IMTSSA-SRI/2000/1266, complete genome \\
\hline AY662691 & Dengue virus type 3 from Singapore, complete genome \\
\hline AY676352 & Dengue virus type 3 strain ThD3_0010_87, complete genome \\
\hline AY676353 & Dengue virus type 3 strain ThD3_0007_87, complete genome \\
\hline AY648961 & Dengue virus type 3 strain Sleman $/ 78$, complete genome \\
\hline AY676350 & Dengue virus type 3 strain ThD3_0104_93, complete genome \\
\hline AY676351 & Dengue virus type 3 strain ThD3_0055_93, complete genome \\
\hline DQ401690 & Dengue virus type 3 isolate InJ-16-82, complete genome \\
\hline AY923865 & Dengue virus type 3 strain C0360/94, complete genome \\
\hline AY744677 & Dengue virus type 3 isolate PF89/27643, complete genome \\
\hline AY744680 & Dengue virus type 3 isolate PF90/3056, complete genome \\
\hline AY744678 & Dengue virus type 3 isolate PF89/320219, complete genome \\
\hline AY744679 & Dengue virus type 3 isolate PF90/3050, complete genome \\
\hline DQ675529 & Dengue virus type 3 isolate 98TW414, complete genome \\
\hline DQ675531 & Dengue virus type 3 isolate 98TW503, complete genome \\
\hline DQ675522 & Dengue virus type 3 isolate $98 \mathrm{TW} 358$, complete genome \\
\hline DQ675520 & Dengue virus type 3 isolate $98 \mathrm{TW} 182$, complete genome \\
\hline DQ675532 & Dengue virus type 3 isolate $98 \mathrm{TWmosq}$, complete genome \\
\hline DQ675530 & Dengue virus type 3 isolate 98TW434, complete genome \\
\hline DQ675526 & Dengue virus type 3 isolate $98 \mathrm{TW} 388$, complete genome \\
\hline DQ675524 & Dengue virus type 3 isolate $98 \mathrm{TW} 364$, complete genome \\
\hline AY744683 & Dengue virus type 3 isolate PF92/2986, complete genome \\
\hline AY744681 & Dengue virus type 3 isolate PF90/6056, complete genome \\
\hline AY876494 & Dengue virus type 3 strain C0331/94, complete genome \\
\hline AF317645 & AF317645 Dengue virus type 3 strain $80-2$, complete genome \\
\hline DQ675527 & Dengue virus type 3 isolate $98 \mathrm{TW} 390$, complete genome \\
\hline DQ675528 & Dengue virus type 3 isolate $98 \mathrm{TW} 407$, complete genome \\
\hline DQ675525 & Dengue virus type 3 isolate $98 \mathrm{TW} 368$, complete genome \\
\hline DQ675523 & Dengue virus type 3 isolate $98 \mathrm{TW} 360$, complete genome \\
\hline DQ675521 & Dengue virus type 3 isolate $98 \mathrm{TW} 349$, complete genome \\
\hline M93130 & DENCME Dengue type 3 virus complete genome RNA, complete cds \\
\hline AY744684 & Dengue virus type 3 isolate PF92/4190, complete genome \\
\hline AY744682 & Dengue virus type 3 isolate PF92/2956, complete genome \\
\hline AY496879 & Dengue virus type 3 isolate PhMH-J1-97, complete genome \\
\hline AY676349 & Dengue virus type 3 strain ThD3_1283_98, complete genome \\
\hline AY676348 & Dengue virus type 3 strain ThD3_1687_98, complete genome \\
\hline AY858038 & Dengue virus type 3 strain den $3 \_88$, complete genome \\
\hline DQ675519 & Dengue virus type 3 isolate $95 \mathrm{TW} 466$, complete genome \\
\hline AY744685 & Dengue virus type 3 isolate PF94/136116, complete genome \\
\hline AB189128 & Dengue virus type 3 genomic RNA, complete genome, strain: 98902890 DF DV-3 \\
\hline AB189126 & Dengue virus type 3 genomic RNA, complete genome, strain: 98901437 DSS DV-3 \\
\hline AY858039 & Dengue virus type 3 strain den3_98, complete genome \\
\hline AB189127 & Dengue virus type 3 genomic RNA \\
\hline AB189125 & Dengue virus type 3 genomic RNA, complete genome, strain: 98901403 DSS DV-3 \\
\hline AY858044 & Dengue virus type 3 strain KJ71, complete genome \\
\hline AY858046 & Dengue virus type 3 strain PI64, complete genome \\
\hline AY858045 & Dengue virus type 3 strain PH86, complete genome \\
\hline AY858041 & Dengue virus type 3 strain FW06, complete genome \\
\hline AY496874 & Dengue virus type 3 isolate $\mathrm{BDH} 02-4$, complete genome \\
\hline AY496873 & Dengue virus type 3 isolate BDH02-3, complete genome \\
\hline AY496871 & Dengue virus type 3 isolate BDH02-1, complete genome \\
\hline AY496877 & Dengue virus type 3 isolate BDH02-7, complete genome \\
\hline AY858040 & Dengue virus type 3 strain FW01, complete genome \\
\hline AY766104 & Dengue virus type 3 strain Singapore $8120 / 95$, complete genome \\
\hline
\end{tabular}




\begin{tabular}{ll}
\hline GenBank & CodeDescription \\
\hline AB214880 & Dengue virus type 3 genomic RNA, neally complete genome, strain:D3/Hu/TL029NIID/2005 \\
AY858048 & Dengue virus type 3 strain TB55i, complete genome \\
AB214881 & Dengue virus type 3 genomic RNA, neally complete genome, strain:D3/Hu/TL109NIID/2005 \\
AB214879 & Dengue virus type 3 genomic RNA, neally complete genome, strain:D3/Hu/TL018NIID/2005 \\
AB214882 & Dengue virus type 3 genomic RNA, neally complete genome, strain:D3/Hu/TL129NIID/2005 \\
AY858043 & Dengue virus type 3 strain KJ46, complete genome \\
AY858037 & Dengue virus type 3 strain BA51, complete genome \\
AY858047 & Dengue virus type 3 strain TB16, complete genome \\
AY858042 & Dengue virus type 3 strain KJ30i, complete genome \\
AY776329 & Dengue virus type 3 strain Taiwan-739079A polyprotein gene, complete cds \\
\hline
\end{tabular}

